\title{
Validation of the pre-treatment neutrophil-lymphocyte ratio as a prognostic factor in a large European cohort of renal cell carcinoma patients
}

\author{
M Pichler ${ }^{\star}, 1$, G C Hutterer ${ }^{2}$, C Stoeckigt ${ }^{1}$, T F Chromecki ${ }^{2}$, T Stojakovic ${ }^{3}$, S Golbeck ${ }^{1}$, K Eberhard ${ }^{4}$, A Gerger ${ }^{1}$, \\ $\mathrm{S}$ Mannweiler ${ }^{5}, \mathrm{~K}$ Pummer ${ }^{2}$ and R Zigeuner ${ }^{2}$ \\ ${ }^{1}$ Division of Oncology, Department of Internal Medicine, Medical University of Graz (MUG), Graz, Austria; ${ }^{2}$ Department of Urology, \\ Medical University of Graz (MUG), Graz, Austria; ${ }^{3}$ Clinical Institute of Medical and Chemical Laboratory Diagnostics, Medical \\ University of Graz (MUG), Graz, Austria; ${ }^{4}$ Research Facility for Biostatistics, Medical University of Graz (MUG), Graz, Austria and \\ ${ }^{5}$ Institute of Pathology, Medical University of Graz (MUG), Graz, Austria
}

Background: The neutrophil-lymphocyte ratio (NLR) has been proposed as an indicator of systemic inflammatory response. Several studies suggest a negative impact of increased NLR for patient's survival in different types of cancer. However, previous findings from small-scale studies revealed conflicting results about its prognostic significance with regard to different clinical end points in non-metastatic renal cell carcinoma (RCC) patients. Therefore, the aim of our study was the validation of the prognostic significance of NLR in a large cohort of RCC patients.

Methods: Data from 678 consecutive non-metastatic clear cell RCC patients, operated between 2000 and 2010 at a single centre, were evaluated retrospectively. Cancer-specific, metastasis-free, as well as overall survival (OS) were assessed using the KaplanMeier method. To evaluate the independent prognostic significance of NLR, multivariate Cox regression models were applied for all three different end points. Influence of the NLR on the predictive accuracy of the Leibovich prognosis score was determined by Harrell's concordance index.

Results: Multivariate analysis identified increased NLR as an independent prognostic factor for overall (hazard ratio $(H R)=1.59$, 95\% confidence interval $(\mathrm{Cl})=1.10-2.31, P=0.014)$, but not for cancer-specific ( $\mathrm{HR}=1.59,95 \% \mathrm{Cl}=0.84-2.99, P=0.148)$, nor for metastasis-free survival $(\mathrm{HR}=1.39,95 \% \mathrm{Cl}=0.85-2.28, P=0.184)$. The estimated concordance index was 0.79 using the Leibovich risk score and 0.81 when NLR was added.

Conclusion: Regarding patients' OS, an increased NLR represented an independent risk factor, which might reflect a higher risk for severe cardiovascular and other comorbidities. Adding the NLR to well-established prognostic models such as the Leibovich prognosis score might improve their predictive ability.

The worldwide incidence rates of renal cell carcinoma (RCC) have slightly increased within the last three decades (Siegel et al, 2012). However, because of the widespread use of radiological imaging techniques, a migration towards small and organ-confined tumours has been observed (Pichler et al, 2012). The use of prognostic factors and models that can accurately predict clinical outcomes of RCC patients are of paramount interest, not only for patients' individualised risk assessment but also for the comparison 
of the results from international clinical multicentre trials (Meskawi et al, 2012). Several prognostic models have been established to predict patient's clinical outcome. Kattan et al (2001) integrated disease-related symptoms, histologic subtype, tumour size and pathologic tumour-node-metastasis (pTNM) stage into their model to predict 5-year treatment failure. The University of California Integrated Staging System (UISS) incorporated performance status, pTNM stage and Fuhrman grade to predict overall survival (OS) in RCC patients (Zisman et al, 2001). The Leibovich prognosis score integrates five clinicopathological features translated into a score and categorises patients into eight-score categories, which are then assigned to one of three different risk groups. According to this score, patients' assignment into the low-, intermediate- or high-risk group can accurately assess the risk for the occurrence of metastatic disease after radical nephrectomy (Leibovich et al, 2003). The accuracy of these models may be further improved by the incorporation of different prognostic biomarkers (Lam et al, 2008). In addition to individual's risk assessment, considering high costs and often toxic side-effects of novel drugs, an accurate identification and validation of prognostic factors will enable a better risk-stratified patient selection for adjuvant treatment modalities (Crispen et al, 2008). External validation of prognostic risk assessment tools using independent cohorts of patients is paramount before the general applicability of a prognostic marker or model (Altman and Royston, 2000; Bleeker et al, 2003).

The systemic inflammatory response, which is usually measured by surrogate blood-based parameters, such as C-reactive protein, neutrophil or platelet count, has been shown to independently predict the clinical outcome of various human cancer types (Roxburgh and McMillan, 2010). Of these inflammatory parameters, an increased neutrophil-lymphocyte ratio (NLR) has been proposed as an easily accessible and reliable marker to predict cancer patients survival (Roxburgh and McMillan, 2010). Cumulating evidence in metastatic RCC suggests that a high NLR might represent an independent adverse prognostic factor in interferontreated (Atzpodien et al, 2003), interleukin-2-treated (Donskov and von der Maase, 2006), as well as in sunitinib-treated (Keizman et al, 2012) patients. However, data regarding the prognostic significance of the NLR in non-metastatic RCC are sparse, and controversy still exists about how discriminating the NLR might potentially be as an independent risk factor in non-metastatic RCC. For instance, in a prospective cohort study including 83 localised RCCs, Ramsey et al (2008) found no statistically significant association of preoperative neutrophil count and patients' relapsefree or CSS. In addition, when evaluating 228 non-metastatic RCC patients, Jagdev et al (2010) also failed to demonstrate an increased NLR to be of independent prognostic value in their cohort study. In contrast, a study from Japan including 192 patients with nonmetastatic RCC, identified a high preoperative NLR as an independent prognostic indicator of patients' relapse-free survival (Ohno et al, 2010). These previously published reports analysed relatively small numbers of patients, heterogeneously histologic subtypes and examined the NLR with regard to different clinical end points. Therefore, the aim of our study was to further clarify the prognostic significance of the preoperative NLR in nonmetastatic clear cell RCC and to evaluate whether this parameter provides additional prognostic information to well-established clinicopathological parameters and to the Leibovich prognosis score (Leibovich et al, 2003).

\section{PATIENTS AND METHODS}

This retrospective analysis included data from 873 consecutive non-metastatic RCC patients who underwent a curative radical or partial nephrectomy at the Department of Urology at the Medical University of Graz, between January 2000 and December 2010. Of this data set, we excluded 195 cases with non-clear cell histology and restricted our analyses to clear cell RCC only, as the evaluated prognostic model (i.e., Leibovich prognosis score) has been previously established on clear cell RCC (Leibovich et al, 2003). All of the clinicopathological data were retrieved from medical records from the Department of Urology, as well as from pathology reports from the Institute of Pathology at the same institution. As the TNM classification system for RCC changed during the observational period, pathologic $\mathrm{T}$ stages were uniformly adjusted according to the seventh edition of the TNM classification system (Novara et al, 2010). Other documented clinicopathological parameters included histological RCC subtype, tumour grade, presence or absence (not quantitatively assessed) of histologic coagulative tumour necrosis (TN), as well as patients' age and gender. The laboratory data, including neutrophil and lymphocyte counts, were obtained by preoperative exploration one day before surgical intervention. Patients' postoperative surveillance included routine clinical and laboratory examination; regarding imaging methods, X-rays of the chest and abdominal ultrasound were predominantly used, especially in patients with a low relapse risk (pT-1 G1-2), whereas computed tomography or magnetic resonance imaging was performed in all other patients as previously reported (Pichler et al, 2011). Follow-up evaluations were performed every 6 months for the first 5 years and annually thereafter for locally advanced tumours. In organ-confined cancers, imaging was performed twice in the first year after surgery and annually thereafter. No neoadjuvant or adjuvant treatment was administered. Dates of death were obtained from the central registry of the Austrian Bureau of Statistics. Cancer-specific survival was defined as the time (in months) from date of surgery to a cancer-related death. Metastasis-free survival (MFS) was defined as the time (in months) from date of surgery to the recurrence of radiologically or histologically confirmed distant metastases. Overall survival was defined as the time (in months) from date of surgery to individuals' death of any cause. The study was approved by the local ethical committee of the Medical University of Graz (no. 24-330 ex 11/12).

Statistical analyses. The primary study end point was CSS, which was calculated from the date of diagnosis to the date of patients' cancer-related death. Secondary end points included OS (the time between diagnosis and death of any cause) and MFS (the time between diagnosis and occurrence of distant metastases). The ideal cutoff value for the continuous NLR was calculated by testing all possible cutoffs that would discriminate between survival and cancer-related death by Cox proportional analyses. The ideal cutoff value was then rounded to clinically relevant (convenient) values as previously reported (Atzpodien et al, 2003).

The relationship between NLR and other clinicopathologic parameters was studied by non-parametric tests. Patients' clinical end points were calculated using the Kaplan-Meier method and compared by the log-rank test. Backward stepwise multivariate Cox proportion analysis was performed to determine the influence of pathologic $\mathrm{T}$ stage, grade, age, gender and histologic TN on CSS, MFS and OS. Hazard ratios (HRs) estimated from the Cox analysis were reported as relative risks with corresponding 95\% confidence intervals (CIs). The patients were categorised according to the Leibovich prognosis risk groups developed for M0 clear cell RCC patients (Leibovich et al, 2003). Harrell's concordance index (cindex) was calculated using the individual Leibovich risk groups followed by the addition of the NLR (Harrell et al, 1982). All statistical analyses were performed using the Statistical Package for Social Sciences version 17.0 (SPSS Inc., Chicago, IL, USA). A twosided $P<0.05$ was considered statistically significant. 


\section{RESULTS}

Of the 843 consecutive RCC patients, 678 (80.4\%) had clear cell, $108(12.8 \%)$ had papillary, $43(5.1 \%)$ had chromophobe, $3(0.4 \%)$ had collecting duct RCC and 11 (1.3\%) were not otherwise specified. For all further analyses, we excluded non-clear cell histology cases resulting in 678 patients with clear cell RCC. Pathologic T stage was T1a in 334 (49.3\%), T1b in 117 (17.3\%), T2a in $32(4.7 \%)$, T2b in $5(0.7 \%)$, T3a in $170(25.1 \%)$, T3b in $16(2.4 \%)$, $\mathrm{T} 3 \mathrm{c}$ in $2(0.3 \%)$ and $\mathrm{T} 4$ in $2(0.3 \%)$ patients. Tumour grading was G1 in $170(25.1 \%)$, G2 in $411(60.6 \%)$ G3 in $92(13.6 \%)$ and G4 in 5 $(0.7 \%)$ cases. Overall, the presence of histologic TN was noted in $165(24.3 \%)$ patients with a mean age of $63.7 \pm 11.9$ years, a mean neutrophil count of $4828 \pm 1974$, a mean lymphocyte count of $1580 \pm 581$ and a mean NLR of $3.51 \pm 2.49$. Applying the criteria mentioned above, we determined a cutoff value of 3.3 for the NLR to be optimal to discriminate between patients' CSS that prompted us to select 3.3 as the optimal cutoff value for all subsequent analyses to differentiate between low $(<3.3)$ and high $(\geqslant 3.3)$ NLR. Overall, there were 398 (58.7\%) patients with a low NLR and 280 (41.3\%) patients with a high NLR. A high NLR was statistically significantly correlated with older age, high tumour grade, large tumour size, as well as with advanced tumour stage (all $P<0.05$ ), but not with gender $(P=0.552)$, the presence of histologic TN $(P=0.107)$ or positive lymph node disease $(P=0.136)$.

To investigate whether the NLR is associated with the clinical outcome of RCC patients, univariable and multivariable analyses for all three end points were performed. Mean follow-up was 44 (range 0-130) months. Of the 678 clear cell RCC patients, 76 $(11.2 \%)$ developed metastatic disease, of which $49(7.2 \%)$ died because of their advanced disease state. Overall, 123 (18.1\%) patients died by their most recent follow-up visit for any cause. Among the 678 RCC patients, metastatic disease was diagnosed in 29 out of $398(7.3 \%)$ patients with a low NLR and in 47 out of 280 $(16.8 \%)$ patients with a high NLR $(P<0.001)$. Regarding survival, cancer-related and overall deaths occurred in 26 (4.0\%) and 52 (13.1\%) patients with low NLR and in $33(11.8 \%)$ and $71(25.4 \%)$ patients with high NLR $(P<0.001)$. Figures 1,2 and 3 show the Kaplan-Meier curves for CSS, MFS and OS and reveal that a high NLR is a consistent factor for poor prognosis in RCC patients $(P<0.001$ for all three tested end points, log-rank test).

Univariate analysis identified age $(\geqslant 65$ vs $<65$ years, $P=0.044)$, high tumour grade $(\mathrm{G} 3+\mathrm{G} 4 v s \mathrm{G} 1+\mathrm{G} 2, P<0.001)$, histologic TN (presence $v s$ absence, $P<0.001$ ), high pathologic $\mathrm{T}$ stage $(\geqslant$ pT3 vs $<$ pT3, $P<0.001)$ and a high NLR $(\geqslant 3.2 v s<3.2$, $P<0.001)$ as prognosticators of poor outcome for patients' CSS, whereas gender (male $v$ s female, $P=0.124$ ) was not statistically significantly associated with CSS (Table 1).

To determine the independent prognostic significance of the NLR for CSS, a multivariate analysis using a Cox proportional hazard model was performed. In our multivariate analysis that included age, pathologic T stage, tumour grade, NLR and presence of histologic TN, we identified age, pathologic $\mathrm{T}$ stage, tumour grade, as well as histologic TN as independent prognostic factors for CSS and MFS, whereas the NLR was not statistically significantly associated with either CSS ( $\mathrm{HR}=1.59, \quad 95 \%$ $\mathrm{CI}=0.84-2.99, \quad P=0.148$, Table 1$)$ or $\mathrm{MFS}(\mathrm{HR}=1.39,95 \%$ $\mathrm{CI}=0.85-2.28, P=0.184$, Table 2). Regarding OS, a high NLR was identified as an independent prognostic factor for poor survival $(\mathrm{HR}=1.59,95 \% \mathrm{CI}=1.10-2.31, P=0.014$, Table 3$)$. Before analysing the addition of the NLR to the Leibovich prognosis model, patients were categorised into risk groups (low, intermediate and high risk) according to Leibovich et al (2003). For MFS, the c-index was 0.79 when assessed with each individual Leibovich risk score and improved to 0.81 when the NLR was added. Regarding CSS, the c-index of the original Leibovich model

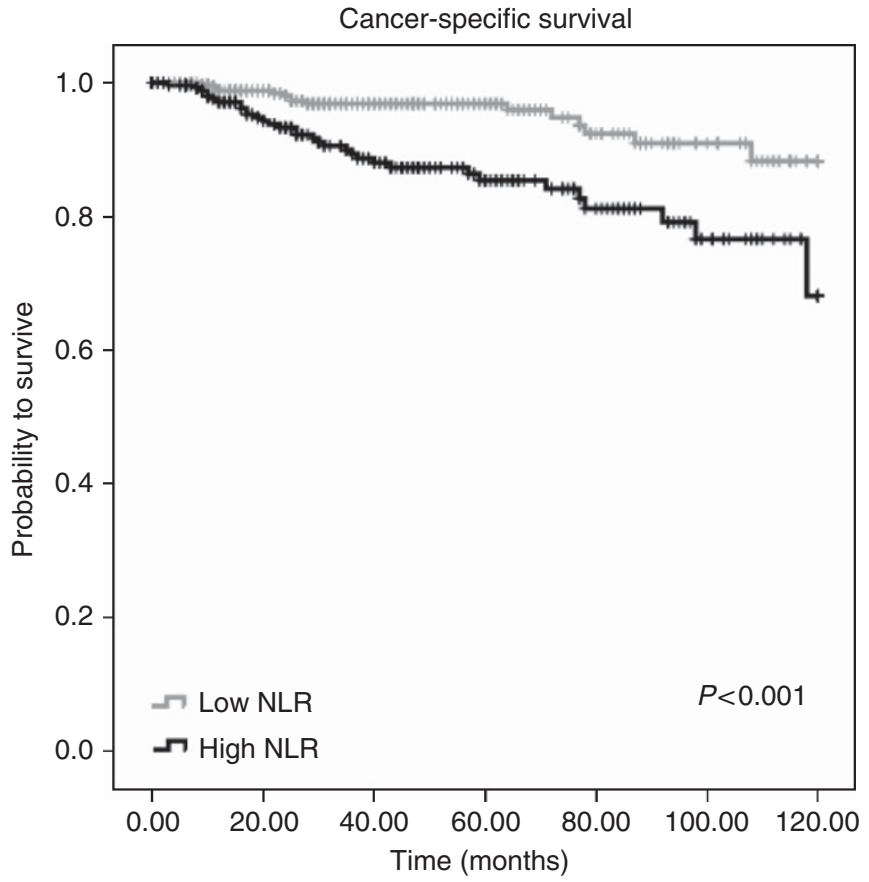

Figure 1. Kaplan-Meier curves for renal cell carcinoma patients cancerspecific survival groups categorised by the neutrophil-lymphocyte ratio (NLR).

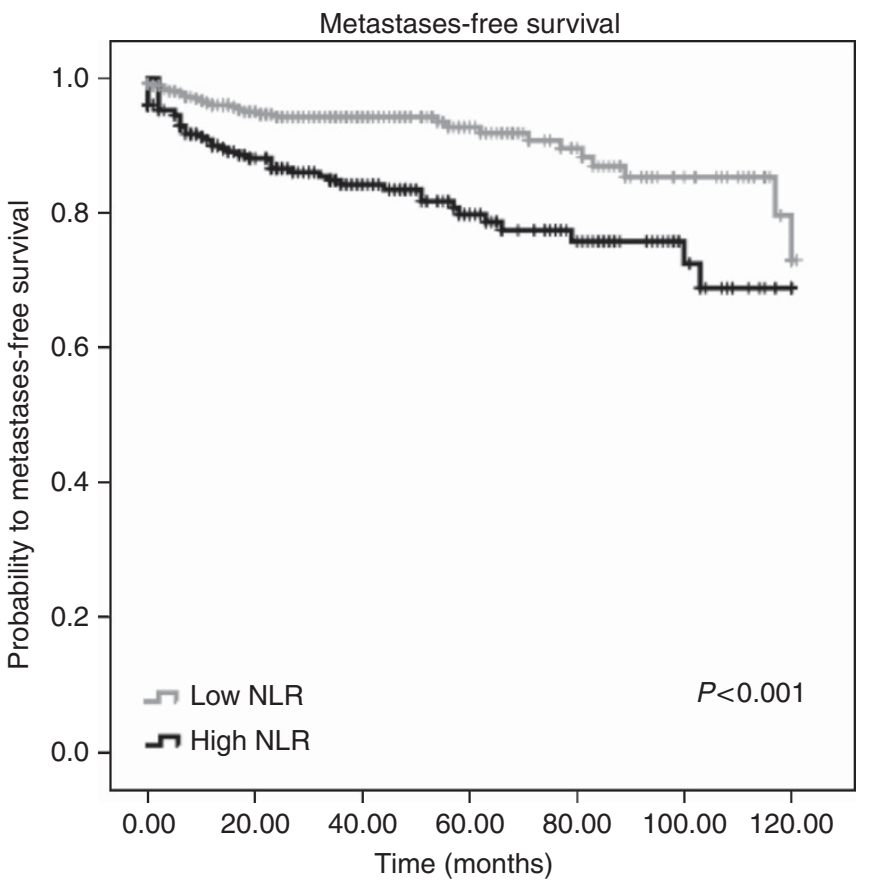

Figure 2. Kaplan-Meier curves for renal cell carcinoma patients metastasis-free survival groups categorised by the neutrophillymphocyte ratio (NLR).

was 0.83 compared with 0.86 when NLR was supplemented. Finally for OS, the c-index improved from 0.63 compared with 0.67 when the NLR was added to the Leibovich prognosis groups.

\section{DISCUSSION}

Despite recent progress in the identification of genetic, epigenetic and common molecular alterations in RCC has been made 
(Al-Ali et al, 2012; Gerlinger et al, 2012), the routine diagnostic and prognostic assessment of RCC currently relies on pathological tissue examination and traditional clinicopathological prognostic variables (Ficarra et al, 2010). The complexity of these molecular changes, as well as high costs of analyses, the time-consuming preparation required and the lack of evidence demonstrating how

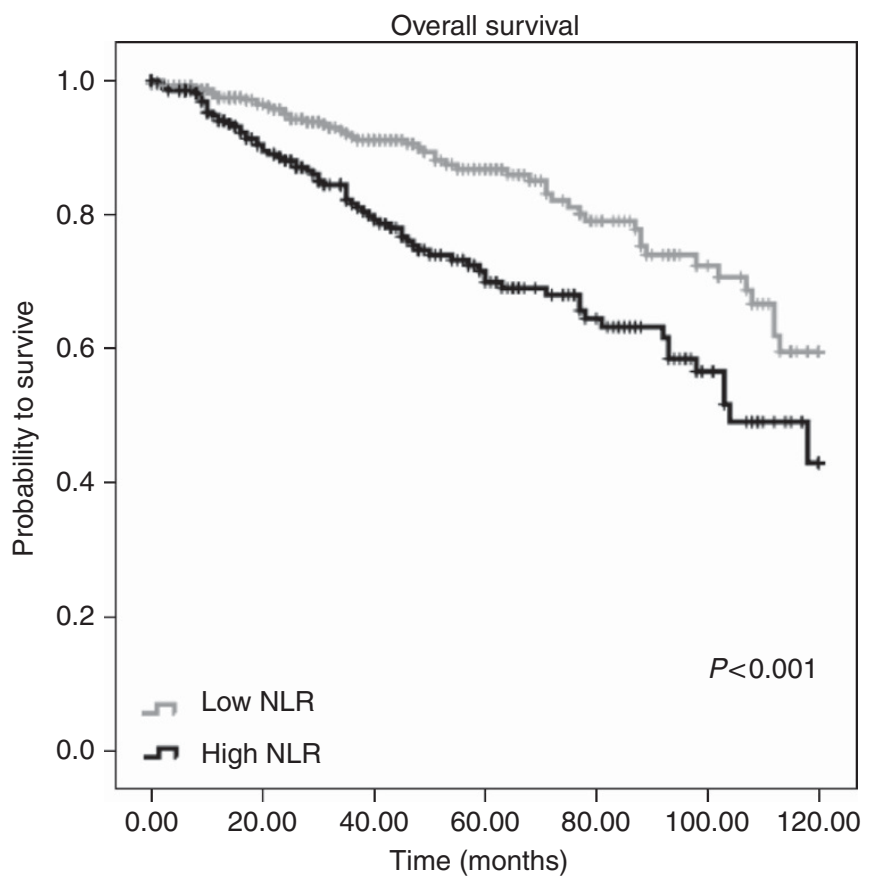

Figure 3. Kaplan-Meier curves for renal cell carcinoma patients overall survival categorised by the neutrophil-lymphocyte ratio (NLR). these newly discovered molecular markers influence diagnostic or therapeutic decisions have rendered none of the markers available for routine testing. Regularly used blood-based parameters, such as the neutrophil or lymphocyte count and the resultant-derived NLR, are relatively easy to assess without additional laborious efforts, making them attractive parameters for patients' improved individualised risk assessment in RCC (Zahorec, 2001).

Heng et al (2009) detected $11.7 \%$ of patients with an increased blood neutrophil count (i.e., cutoff value defined as greater than the upper limit of normal range) and showed that the blood neutrophils only represent an independent prognostic factor in metastatic RCC patients. However, in our study we only could identify $15(2.2 \%)$ patients with an increased blood neutrophil count only (i.e., greater than the upper limit of normal range), which represents a too low number of patients to perform a reliable multivariate prognostic analysis.

Beyond the neutrophil count only, an increased pre-treatment NLR has been previously demonstrated as a poor prognostic factor for different human cancer types, including gastrointestinal, soft tissue sarcoma, nasopharyngeal, as well as lung cancer (Roxburgh and McMillan, 2010). In non-metastatic RCC, only two studies have been published about the prognostic value of the pretreatment NLR so far, and the reported findings are conflicting. In our validation study that included a large middle European cohort of 678 patients with non-metastatic clear cell RCC, we were able to demonstrate that an increased NLR was an independent negative predictor for patients' OS but not a predictor for direct cancerrelated end points, such as CSS and MFS. To the best of our knowledge, our study represents one of the most comprehensive ones to date testing the independent prognostic significance of the NLR in clear cell RCC. Our findings are in agreement with the study of Jagdev et al (2010), who did not find an independent prognostic significance for the NLR in 228 non-metastatic RCC patients with regard to CSS and disease-free survival. In contrast to Jagdev et al's and our negative findings, Ohno et al (2010) reported

Table 1. Univariate and multivariate analysis of clinicopathological parameters for the prediction of cancer-specific survival in patients with clear cell renal cell carcinoma $(n=678)$

Parameter

Univariate analysis

\begin{tabular}{l|l} 
HR $(95 \% \mathrm{Cl})$ & $P$-value
\end{tabular}

Age at operation (years)

$<65$

$\geqslant 65$

\section{Gender}

\section{Female}

Male

T stage

PT1-2

pT3-4

Tumour grade

\section{$\mathrm{G} 1+\mathrm{G} 2$}

$\mathrm{G} 3+\mathrm{G} 4$

\section{Presence of tumour necrosis}

\begin{tabular}{|c|c|c|c|c|}
\hline $\begin{array}{l}\text { No } \\
\text { Yes }\end{array}$ & $\begin{array}{c}1 \text { (Referent) } \\
4.25(2.42-7.47)\end{array}$ & $<0.001$ & $\begin{array}{c}1 \text { (Referent) } \\
2.55(1.41-4.63)\end{array}$ & 0.002 \\
\hline \multicolumn{5}{|c|}{ Neutrophil-lymphocyte ratio } \\
\hline $\begin{array}{l}<3.3 \\
\geqslant 3.3\end{array}$ & $\begin{array}{c}1 \text { (Referent) } \\
2.89(1.59-5.22)\end{array}$ & $<0.001$ & $\begin{array}{c}1 \text { (Referent) } \\
1.59(0.84-2.99)\end{array}$ & 0.148 \\
\hline
\end{tabular}


Table 2. Univariate and multivariate analysis of clinicopathological parameters for the prediction of metastasis-free survival in patients with clear cell renal cell carcinoma $(n=678)$

\begin{tabular}{|c|c|c|c|c|}
\hline \multirow[t]{2}{*}{ Parameter } & \multicolumn{2}{|c|}{ Univariate analysis } & \multicolumn{2}{|c|}{ Multivariate analysis } \\
\hline & $\mathrm{HR}(95 \% \mathrm{Cl})$ & $\boldsymbol{P}$-value & $\mathrm{HR}(95 \% \mathrm{Cl})$ & $\boldsymbol{P}$-value \\
\hline \multicolumn{5}{|c|}{ Age at operation (years) } \\
\hline $\begin{array}{l}<65 \\
\geqslant 65\end{array}$ & $\begin{array}{c}1 \text { (Referent) } \\
1.23(0.78-1.94) \\
\end{array}$ & 0.357 & $\begin{array}{c}1 \text { (Referent) } \\
1.07(0.68-1.71) \\
\end{array}$ & 0.747 \\
\hline \multicolumn{5}{|l|}{ Gender } \\
\hline $\begin{array}{l}\text { Female } \\
\text { Male }\end{array}$ & $\begin{array}{c}1 \text { (Referent) } \\
1.51(0.96-2.37)\end{array}$ & 0.072 & & \\
\hline \multicolumn{5}{|l|}{ T stage } \\
\hline $\begin{array}{l}\text { pT1-2 } \\
\text { pT3-4 }\end{array}$ & $\begin{array}{c}1 \text { (Referent) } \\
5.69(3.52-9.19)\end{array}$ & $<0.001$ & $\begin{array}{c}1 \text { (Referent) } \\
3.47(2.06-5.84)\end{array}$ & $<0.001$ \\
\hline \multicolumn{5}{|c|}{ Tumour grade } \\
\hline $\begin{array}{l}\mathrm{G} 1+\mathrm{G} 2 \\
\mathrm{G} 3+\mathrm{G} 4\end{array}$ & $\begin{array}{c}1 \text { (Referent) } \\
6.08(3.83-9.64)\end{array}$ & $<0.001$ & $\begin{array}{c}1 \text { (Referent) } \\
2.69 \text { (1.61-4.49) }\end{array}$ & $<0.001$ \\
\hline \multicolumn{5}{|c|}{ Presence of tumour necrosis } \\
\hline $\begin{array}{l}\text { No } \\
\text { Yes }\end{array}$ & $\begin{array}{c}1 \text { (Referent) } \\
3.80(2.42-5.96) \\
\end{array}$ & $<0.001$ & $\begin{array}{c}1 \text { (Referent) } \\
2.22(1.38-3.59) \\
\end{array}$ & 0.001 \\
\hline \multicolumn{5}{|c|}{ Neutrophil-lymphocyte ratio } \\
\hline $\begin{array}{l}<3.3 \\
\geqslant 3.3\end{array}$ & $\begin{array}{c}1 \text { (Referent) } \\
2.37(1.49-3.76)\end{array}$ & $<0.001$ & $\begin{array}{c}1 \text { (Referent) } \\
1.39(0.85-2.28)\end{array}$ & 0.184 \\
\hline
\end{tabular}

Table 3. Univariate and multivariate analysis of clinicopathological parameters for the prediction of overall survival in patients with clear cell renal cell carcinoma $(n=678)$

\begin{tabular}{|c|c|c|c|c|}
\hline \multirow[t]{2}{*}{ Parameter } & \multicolumn{2}{|c|}{ Univariate analysis } & \multicolumn{2}{|c|}{ Multivariate analysis } \\
\hline & $\mathrm{HR}(95 \% \mathrm{Cl})$ & $P$-value & $\mathrm{HR}(95 \% \mathrm{Cl})$ & $\boldsymbol{P}$-value \\
\hline \multicolumn{5}{|c|}{ Age at operation (years) } \\
\hline $\begin{array}{l}<65 \\
\geqslant 65\end{array}$ & $\begin{array}{c}1 \text { (Referent) } \\
2.14(1.46-3.14) \\
\end{array}$ & $<0.001$ & $\begin{array}{c}1 \text { (Referent) } \\
2.03(1.39-2.99) \\
\end{array}$ & $<0.001$ \\
\hline \multicolumn{5}{|l|}{ Gender } \\
\hline $\begin{array}{l}\text { Female } \\
\text { Male }\end{array}$ & $\begin{array}{c}1 \text { (Referent) } \\
1.02(0.71-1.47)\end{array}$ & 0.894 & & \\
\hline \multicolumn{5}{|l|}{ T stage } \\
\hline $\begin{array}{l}\text { pT1-2 } \\
\text { pT3-4 }\end{array}$ & $\begin{array}{c}1 \text { (Referent) } \\
1.92(1.34-2.75)\end{array}$ & $<0.001$ & $\begin{array}{c}1 \text { (Referent) } \\
1.47(1.00-2.18)\end{array}$ & 0.048 \\
\hline \multicolumn{5}{|c|}{ Tumour grade } \\
\hline $\begin{array}{l}\mathrm{G} 1+\mathrm{G} 2 \\
\mathrm{G} 3+\mathrm{G} 4\end{array}$ & $\begin{array}{c}1 \text { (Referent) } \\
2.50(1.64-3.84)\end{array}$ & $<0.001$ & $\begin{array}{c}1 \text { (Referent) } \\
1.72(1.16-2.78)\end{array}$ & 0.027 \\
\hline \multicolumn{5}{|c|}{ Presence of tumour necrosis } \\
\hline $\begin{array}{l}\text { No } \\
\text { Yes }\end{array}$ & $\begin{array}{c}1 \text { (Referent) } \\
1.43(0.97-2.11)\end{array}$ & 0.068 & $\begin{array}{c}1 \text { (Referent) } \\
1.15 \text { (0.76-1.73) }\end{array}$ & 0.493 \\
\hline \multicolumn{5}{|c|}{ Neutrophil-lymphocyte ratio } \\
\hline $\begin{array}{l}<3.3 \\
\geqslant 3.3\end{array}$ & $\begin{array}{c}1 \text { (Referent) } \\
1.93(1.35-2.77)\end{array}$ & $<0.001$ & $\begin{array}{c}1 \text { (Referent) } \\
1.59(1.10-2.31)\end{array}$ & 0.014 \\
\hline
\end{tabular}

that an increased NLR was an independent predictor for relapsefree survival in a smaller cohort of 192 RCC patients from Japan. However, in addition to the significantly smaller sample size and a different ethnic background, Ohno et al did not include commonly used prognostic factors in their multivariate model, such as tumour grade or histologic TN (Sun et al, 2011). Interestingly, we found that the NLR was an independent prognostic factor for OS, which might possibly reflect a higher overall mortality rate for patients 
with increased systemic inflammatory responses. However, a definitive explanation for this observation remains speculative. Nevertheless, several studies evaluating the NLR as an adverse factor in cardiovascular diseases included several thousands of patients and have clearly established an increased NLR as a negative prognostic predictor for cardiovascular events. For instance, Tsai et al (2007) demonstrated in 1872 subjects that the NLR, in addition to metabolic syndrome, is strongly associated with the risk of ischaemic cardiovascular diseases. Other studies have indicated an increased NLR to be associated with poor survival after coronary artery bypass grafting (Gibson et al, 2007), to be an independent predictor of in-hospital and 6-month mortality in patients with acute coronary syndrome (Tamhane et al, 2008) and to be an independent predictor of in-hospital major adverse cardiac events in patients with ST-segment elevation myocardial infarction (Akpek et al, 2012). Imtiaz et al (2012) described an increased NLR in patients with hypertension and diabetes, and Terradas et al (2012) found that an increased NLR was an independent marker of mortality in patients with bacteraemia. Furthermore, one recently published report demonstrated that stage 4 chronic kidney disease patients with a high NLR had a worse prognosis and a significantly faster progression to dialysis compared with those with a low NLR (Kocyigit et al, 2012). In this context, Sun et al (2012) demonstrated that the status of chronic kidney disease is getting worse after nephrectomy, which might contribute to a higher overall mortality in patients with an increased systemic inflammatory response found in our study. Evidence also exists that an increased NLR might represent a marker for more severe gastrointestinal conditions, such as a higher risk for non-alcoholic steatohepatitis and fibrosis of the liver (Alkhouri et al, 2012), as well as adverse outcomes because of acute pancreatitis (Azab et al, 2011).

Taken together, these data support the hypothesis that an increased NLR seems to be associated with patients' increased risk of cardiovascular, infectious and gastrointestinal morbidity and mortality, and may underlie the increased overall mortality we observed in our cohort of RCC patients with an increased NLR. One caveat to consider is that although the NLR is easy to measure, the specificity of this parameter is influenced by several other conditions such as active infection, inflammatory diseases, smoking behaviour or stress at the time of blood collection (Pedersen et al, 1999; Alkhouri et al, 2012). In our opinion, these factors impair the use and generalisability of this marker as a specific predictor of survival in patient cohorts.

Several studies indicated that tumour infiltrating neutrophils or lymphocyte subtypes might have a meaningful role for the biological behaviour of tumour cells in RCC. For instance, Jensen et al (2009) demonstrated that a high number of intratumoural neutrophils is a strong and independent poor prognostic factor for the clinical outcome in localised clear cell RCC. In a study by Kondo et al (2004) the authors demonstrated a favourable outcome for RCC's where high levels of lymphocytic attractant chemokines are expressed. Hotta et al (2011) postulated that the intratumoural $\mathrm{CD} 45 \mathrm{RO}+$ memory T-cell status has a significant independent prognostic value, indicating that the adaptive immune response is functionally critical in human RCC. Cumulating data also indicated that $\mathrm{T}$ regulatory cells, which are detectable by different markers such as CD4CD25 positivity and intracytoplasmic-Foxp3 expression, are involved in RCC progression and RCC prognosis (Siddiqui et al, 2007; Jeron et al, 2009; Liotta et al, 2011).

As with all retrospective studies, limitations of our study are inherent to its design including the retrospective data collection. No data were available about the cause of death for calculation of patients' OS; hence, the reasons for an elevated death rate in the group of patients with an increased preoperative NLR remain elusive. In an attempt to control for the homogeneity of the study population, we excluded patients with non-clear cell histology, hereditary RCC, patients with metachronous secondary RCC and those with competitive invasive cancers originating from other sites if metastatic spread was not assessed through histologic examination. In addition to the evaluation of the integration of the NLR to the Leibovich prognosis score, other prognostic models such as the Kattan nomogram (Kattan et al, 2001) or the UISS model (Zisman et al, 2001) should be evaluated.

Nonetheless, even considering these limitations, our data clearly indicate that an increased pre-treatment NLR might represent an independent prognostic factor for OS in non-metastatic clear cell RCC patients.

In conclusion, an increased NLR seems to represent an independent predictor with respect to patients' OS in nonmetastatic RCC. As the NLR improves the prognostic accuracy of the Leibovich prognosis score, this parameter warrants further validation as a selection criterion for risk factor-stratified patient management in non-metastatic RCC.

\section{ACKNOWLEDGEMENTS}

None of the contributing authors have any conflicts of interest, including specific financial interests and relationships and affiliations relevant to the subject matter or materials discussed in the manuscript.

\section{REFERENCES}

Akpek M, Kaya MG, Lam YY, Sahin O, Elcik D, Celik T, Ergin A, Gibson CM (2012) Relation of neutrophil/lymphocyte ratio to coronary flow to inhospital major adverse cardiac events in patients with ST-elevated myocardial infarction undergoing primary coronary intervention. Am J Cardiol 110(5): 621-627.

Al-Ali BM, Ress AL, Gerger A, Pichler M (2012) MicroRNAs in renal cell carcinoma: implications for pathogenesis, diagnosis, prognosis and therapy. Anticancer Res 32(9): 3727-3732.

Alkhouri N, Morris-Stiff G, Campbell C, Lopez R, Tamimi TA, Yerian L, Zein NN, Feldstein AE (2012) Neutrophil to lymphocyte ratio: a new marker for predicting steatohepatitis and fibrosis in patients with nonalcoholic fatty liver disease. Liver Int 32(2): 297-302.

Altman DG, Royston P (2000) What do we mean by validating a prognostic model? Stat Med 19(4): 453-473.

Atzpodien J, Royston P, Wandert T, Reitz M (2003) Metastatic renal carcinoma comprehensive prognostic system. Br J Cancer 88(3): 348-353.

Azab B, Jaglall N, Atallah JP, Lamet A, Raja-Surya V, Farah B, Lesser M, Widmann WD (2011) Neutrophil-lymphocyte ratio as a predictor of adverse outcomes of acute pancreatitis. Pancreatology 11(4): 445-452.

Bleeker SE, Moll HA, Steyerberg EW, Donders AR, Derksen-Lubsen G, Grobbee DE, Moons KG (2003) External validation is necessary in prediction research: a clinical example. J Clin Epidemiol 56(9): 826-832.

Crispen PL, Boorjian SA, Lohse CM, Leibovich BC, Kwon ED (2008) Predicting disease progression after nephrectomy for localized renal cell carcinoma: the utility of prognostic models and molecular biomarkers. Cancer 113(3): 450-460.

Donskov F, von der Maase H (2006) Impact of immune parameters on longterm survival in metastatic renal cell carcinoma. J Clin Oncol 24(13): 1997-2005.

Ficarra V, Brunelli M, Cheng L, Kirkali Z, Lopez-Beltran A, Martignoni G, Montironi R, Novara G, Van Poppel H (2010) Prognostic and therapeutic impact of the histopathologic definition of parenchymal epithelial renal tumors. Eur Urol 58(5): 655-668.

Gerlinger M, Rowan AJ, Horswell S, Larkin J, Endesfelder D, Gronroos E, Martinez P, Matthews N, Stewart A, Tarpey P, Varela I, Phillimore B, Begum S, McDonald NQ, Butler A, Jones D, Raine K, Latimer C, Santos CR, Nohadani M, Eklund AC, Spencer-Dene B, Clark G, Pickering L, Stamp G, Gore M, Szallasi Z, Downward J, Futreal PA, Swanton C (2012) Intratumor heterogeneity and branched evolution revealed by multiregion sequencing. $N$ Engl J Med 366(10): 883-892. 
Gibson PH, Croal BL, Cuthbertson BH, Small GR, Ifezulike AI, Gibson G, Jeffrey RR, Buchan KG, El-Shafei H, Hillis GS (2007) Preoperative neutrophil-lymphocyte ratio and outcome from coronary artery bypass grafting. Am Heart J 154(5): 995-1002.

Harrell Jr. FE, Califf RM, Pryor DB, Lee KL, Rosati RA (1982) Evaluating the yield of medical tests. JAMA 247(18): 2543-2546.

Heng DY, Xie W, Regan MM, Warren MA, Golshayan AR, Sahi C, Eigl BJ, Ruether JD, Cheng T, North S, Venner P, Knox JJ, Chi KN,

Kollmannsberger C, McDermott DF, Oh WK, Atkins MB, Bukowski RM, Rini BI, Choueiri TK (2009) Prognostic factors for overall survival in patients with metastatic renal cell carcinoma treated with vascular endothelial growth factor-targeted agents: results from a large, multicenter study. J Clin Oncol 27(34): 5794-5799.

Hotta K, Sho M, Fujimoto K, Shimada K, Yamato I, Anai S, Konishi N, Hirao Y, Nonomura K, Nakajima Y (2011) Prognostic significance of CD45RO + memory T cells in renal cell carcinoma. Br J Cancer 105(8): 1191-1196.

Imtiaz F, Shafique K, Mirza SS, Ayoob Z, Vart P, Rao S (2012) Neutrophil lymphocyte ratio as a measure of systemic inflammation in prevalent chronic diseases in Asian population. Int Arch Med 5(1): 2.

Jagdev SP, Gregory W, Vasudev NS, Harnden P, Sim S, Thompson D, Cartledge J, Selby PJ, Banks RE (2010) Improving the accuracy of preoperative survival prediction in renal cell carcinoma with C-reactive protein. Br J Cancer 103(11): 1649-1656.

Jensen HK, Donskov F, Marcussen N, Nordsmark M, Lundbeck F, von der Maase H (2009) Presence of intratumoral neutrophils is an independent prognostic factor in localized renal cell carcinoma. J Clin Oncol 27(28): 4709-4717.

Jeron A, Pfoertner S, Bruder D, Geffers R, Hammerer P, Hofmann R, Buer J, Schrader AJ (2009) Frequency and gene expression profile of regulatory $\mathrm{T}$ cells in renal cell carcinoma. Tumour Biol 30(3): 160-170.

Kattan MW, Reuter V, Motzer RJ, Katz J, Russo P (2001) A postoperative prognostic nomogram for renal cell carcinoma. J Urol 166(1): 63-67.

Keizman D, Ish-Shalom M, Huang P, Eisenberger MA, Pili R, Hammers H, Carducci MA (2012) The association of pre-treatment neutrophil to lymphocyte ratio with response rate, progression free survival and overall survival of patients treated with sunitinib for metastatic renal cell carcinoma. Eur J Cancer 48(2): 202-208.

Kocyigit I, Eroglu E, Unal A, Sipahioglu MH, Tokgoz B, Oymak O, Utas C (2012) Role of neutrophil/lymphocyte ratio in prediction of disease progression in patients with stage- 4 chronic kidney disease. J Nephrol; e-pub ahead of print 8 May 2012; doi:10.5301/jn.5000152.

Kondo T, Ito F, Nakazawa H, Horita S, Osaka Y, Toma H (2004) High expression of chemokine gene as a favorable prognostic factor in renal cell carcinoma. J Urol 171(6 Pt 1): 2171-2175.

Lam JS, Klatte T, Kim HL, Patard JJ, Breda A, Zisman A, Pantuck AJ, Figlin RA (2008) Prognostic factors and selection for clinical studies of patients with kidney cancer. Critical Rev Oncol/Hematol 65(3): 235-262.

Leibovich BC, Blute ML, Cheville JC, Lohse CM, Frank I, Kwon ED, Weaver AL, Parker AS, Zincke H (2003) Prediction of progression after radical nephrectomy for patients with clear cell renal cell carcinoma: a stratification tool for prospective clinical trials. Cancer 97(7): 1663-1671.

Liotta F, Gacci M, Frosali F, Querci V, Vittori G, Lapini A, Santarlasci V, Serni S, Cosmi L, Maggi L, Angeli R, Mazzinghi B, Romagnani P, Maggi E, Carini M, Romagnani S, Annunziato F (2011) Frequency of regulatory T cells in peripheral blood and in tumour-infiltrating lymphocytes correlates with poor prognosis in renal cell carcinoma. BJU Int 107(9): 1500-1506.

Meskawi M, Sun M, Trinh QD, Bianchi M, Hansen J, Tian Z, Rink M, Ismail S, Shariat SF, Montorsi F, Perrotte P, Karakiewicz PI (2012) A review of integrated staging systems for renal cell carcinoma. Eur Urol 62(2): 303-314.

Novara G, Ficarra V, Antonelli A, Artibani W, Bertini R, Carini M, Cosciani Cunico S, Imbimbo C, Longo N, Martignoni G, Martorana G, Minervini A, Mirone V, Montorsi F, Schiavina R, Simeone C, Serni S, Simonato A, Siracusano S, Volpe A, Carmignani G (2010) Validation of the 2009 TNM version in a large multi-institutional cohort of patients treated for renal cell carcinoma: are further improvements needed? Eur Urol 58(4): 588-595.
Ohno Y, Nakashima J, Ohori M, Hatano T, Tachibana M (2010) Pretreatment neutrophil-to-lymphocyte ratio as an independent predictor of recurrence in patients with nonmetastatic renal cell carcinoma. J Urol 184(3): 873-878.

Pedersen BK, Bruunsgaard H, Jensen M, Krzywkowski K, Ostrowski K (1999) Exercise and immune function: effect of ageing and nutrition. Proc Nutr Soc 58(3): 733-742.

Pichler M, Hutterer GC, Chromecki TF, Jesche J, Kampel-Kettner K, Pummer K, Zigeuner R (2012) Renal cell carcinoma stage migration in a single European centre over 25 years: effects on 5- and 10-year metastasisfree survival. Int Urol Nephrol 44(4): 997-1004.

Pichler M, Hutterer GC, Chromecki TF, Jesche J, Kampel-Kettner K, Rehak P, Pummer K, Zigeuner R (2011) External validation of the Leibovich prognosis score for nonmetastatic clear cell renal cell carcinoma at a single European center applying routine pathology. J Urol 186(5): 1773-1777.

Ramsey S, Lamb GW, Aitchison M, McMillan DC (2008) Prospective study of the relationship between the systemic inflammatory response, prognostic scoring systems and relapse-free and cancer-specific survival in patients undergoing potentially curative resection for renal cancer. BJU Int 101(8): 959-963.

Roxburgh CS, McMillan DC (2010) Role of systemic inflammatory response in predicting survival in patients with primary operable cancer. Future Oncol 6(1): 149-163.

Siddiqui SA, Frigola X, Bonne-Annee S, Mercader M, Kuntz SM, Krambeck AE, Sengupta S, Dong H, Cheville JC, Lohse CM, Krco CJ, Webster WS, Leibovich BC, Blute ML, Knutson KL, Kwon ED (2007) Tumor-infiltrating Foxp3-CD4 + CD25 + T cells predict poor survival in renal cell carcinoma. Clin Cancer Res 13(7): 2075-2081.

Siegel R, Naishadham D, Jemal A (2012) Cancer statistics, 2012. CA Cancer J Clin 62(1): 10-29.

Sun M, Bianchi M, Hansen J, Trinh QD, Abdollah F, Tian Z, Sammon J, Shariat SF, Graefen M, Montorsi F, Perrotte P, Karakiewicz PI (2012) Chronic kidney disease after nephrectomy in patients with small renal masses: a retrospective observational analysis. Eur Urol 62(4): 696-703.

Sun M, Shariat SF, Cheng C, Ficarra V, Murai M, Oudard S, Pantuck AJ, Zigeuner R, Karakiewicz PI (2011) Prognostic factors and predictive models in renal cell carcinoma: a contemporary review. Eur Urol 60(4): 644-661.

Tamhane UU, Aneja S, Montgomery D, Rogers EK, Eagle KA, Gurm HS (2008) Association between admission neutrophil to lymphocyte ratio and outcomes in patients with acute coronary syndrome. Am J Cardiol 102(6): 653-657.

Terradas R, Grau S, Blanch J, Riu M, Saballs P, Castells X, Horcajada JP, Knobel H (2012) Eosinophil count and neutrophil-lymphocyte count ratio as prognostic markers in patients with bacteremia: a retrospective cohort study. PloS one 7(8): e42860.

Tsai JC, Sheu SH, Chiu HC, Chung FM, Chang DM, Chen MP, Shin SJ, Lee YJ (2007) Association of peripheral total and differential leukocyte counts with metabolic syndrome and risk of ischemic cardiovascular diseases in patients with type 2 diabetes mellitus. Diabetes/Metabol Res Rev 23(2): $111-118$.

Zahorec R (2001) Ratio of neutrophil to lymphocyte counts-rapid and simple parameter of systemic inflammation and stress in critically ill. Bratisl Lek Listy 102(1): 5-14.

Zisman A, Pantuck AJ, Dorey F, Said JW, Shvarts O, Quintana D, Gitlitz BJ, deKernion JB, Figlin RA, Belldegrun AS (2001) Improved prognostication of renal cell carcinoma using an integrated staging system. J Clin Oncol 19(6): 1649-1657.

This work is published under the standard license to publish agreement. After 12 months the work will become freely available and the license terms will switch to a Creative Commons AttributionNonCommercial-Share Alike 3.0 Unported License. 